\section{Thoracomelia in sheep: a case report}

\section{Toracomelia em ovino: relato de caso}

\author{
Eder Sardinha Silva' (1), Vanessa Silva Mustafa² (1), Paula Aguiar Sá3 ${ }^{\text {(1) }}$ \& Rita de Cássia Campebell ${ }^{4 *}$ (1) \\ 'Veterinary, Autonomus. Brasília, DF, Brasil \\ Veterinary, Dr. Departamento de Medicina Veterinária, Centro Universitário do Planalto Central Apparecido dos Santos - \\ UNICEPLAC, Brasília, DF, Brasil \\ Veterinary, MSc. Faculdade de Agronomia e Medicina Veterinária - FAV, Universidade de Brasília - UnB, Brasília, DF, Brasil \\ ${ }^{4}$ Veterinary, Dr. Faculdade de Agronomia e Medicina Veterinária - FAV, Universidade de Brasília - UnB, Brasília, DF, Brasil
}

\begin{abstract}
In this case report, the occurrence of thoracomelia in a female sheep is reported. Thoracomelia is a congenital malformation that can affect several animal species and is characterized by the presence of a supernumerary limb in the thoracic region. Scientific studies regarding the etiology of changes of this nature are limited in veterinary medicine, especially concerning sheep. So far, there is no consensus regarding if the origin of this congenital malformation is genetic or environmental. Here, we provide the historical and photographic record of thoracomelia in a female sheep, and relate the malformation to an environmental cause: physical aggression suffered during embryonic development. The sheep underwent a surgical procedure for removal of the accessory limb and subsequently remained in the breeding line, giving birth to healthy descendants without thoracomelia.
\end{abstract}

Keywords: aggression, congenital malformation, etiology, polymelia, reproduction.

\section{Resumo}

Relata-se a ocorrência de toracomelia em ovelha, uma malformação congênita caracterizada pela presença de membro supranumerário na região torácica e que pode acometer diversas espécies animais. Estudos científicos a respeito da etiologia de alterações dessa natureza são limitados na Medicina Veterinária, especialmente em relação a ovinos, não havendo consenso se a origem é genética ou ambiental. Esse relato de caso disponibiliza o registro histórico e fotográfico da toracomelia, e relaciona a malformação a origem ambiental, devido a agressão física sofrida durante o desenvolvimento embrionário. A ovelha foi submetida a procedimento cirúrgico para exérese do membro acessório e, mantida na linha de reprodução, originando descendentes normais.

Palavras-chave: agressão, malformação congênita, etiologia, polimelia, reprodução.

\section{BJ $\otimes M$}

How to cite: Silva, E. S., Mustafa, V.S., Sá, P.A., \& Campebell, R. C. (2020). Thoracomelia in sheep: a case report. Brazilian Journal of Veterinary Medicine, 42, el08220. doi: 10.29374/2527-2179. bjvm108220

\section{Financial support: None}

Conflict of interests: No conflict of interests declared concerning the publication of this article.

Received: October 04, 2019.

Accepted: April 08, 2010

The study was carried out at Departamento de Medicina Veterinária, Hospital Veterinário, Centro Universitário do Planalto Central Apparecido dos Santos - UNICEPLAC, Brasília, DF, Brasil.

\section{*Correspondence}

Rita de Cássia Campebell

Faculdade de Agronomia e Medicina Veterinária - FAV, Universidade de Brasília - UnB Campos Universitário Darcy Ribeiro, Asa Norte CEP 70910-970 - Brasília (DF), Brasil

E-mail: campbellvetdr@gmail.com
Copyright Silva et al. This is an Open Access article distributed under the terms of the Creative Commons Attribution Non-Commercial License which permits unrestricted non-commercial use, distribution, and reproduction in any medium provided the original work is properly cited. 


\section{Introduction}

Heterotopic polymelia is characterized by the presence of supernumerary limbs, which are usually accessory and non-functional. When the accessory limb is located on the thorax, the deformity is classified as thoracomelia. Such occurrences can be caused by embryonic cell death or injury (Werner, 2011). This type of malformation is more common in cattle, with accessory limbs tending to be small and deformed (Wammes et al., 2013).

The worldwide occurrence of congenital defects in sheep is estimated to be between $0.2 \%$ and $2 \%$. However, scientific knowledge about such defects is limited; one of the reasons for this is the lack of laboratory studies that analyze lambs with such defects (Pereira et al., 2010). Thus, in veterinary medicine, etiological studies of these deformities are often based on archeozoological findings, which are limited by three main factors. First, anatomical knowledge is often lacking and methodologies are inconsistent when such findings have occurred at random in field bone collections. Second, deaths in the perinatal period lead to rapid decomposition of structures due to low bone mineralization. Third, deformities of genetic origin usually affect soft tissues, and these are always absent in archeozoological findings (Paukovics, 2013).

A survey conducted at the Regional Diagnostic Laboratory (Laboratório Regional de Diagnóstico; LRD) of the Faculty of Veterinary Medicine, Federal University of Pelotas (UFPel; Pelotas, Rio Grande do Sul State, Brazil) identified congenital defects in only 3 of 843 sheep samples received for analysis; of these, none referred to polymelia (Pereira et al., 2010). Moreover, a study in the semiarid region of Paraíba State, Brazil, concluded that malformations caused 23.3\% of lamb deaths, surpassed only by neonatal infections (41.1\%). This study suggested that these malformations were caused by toxic plants (Nóbrega Junior et al., 2005).

Evaluations of polydactyly in cattle, canines, cats, and humans have identified the presence of an autosomal dominant gene with incomplete penetrance (Anjos et al., 2015). Similar studies have not been conducted for horses (Canola et al., 1993). However, another theory is that polymelia is a nonhereditary congenital malformation, likely with a multifactorial cause, which can be associated with erratic dispersion of embryonic germ cells (Cebrián et al., 2006).

There is no consensus on whether congenital duplicates have a genetic or environmental origin; in fact, these changes appear to have a multifactorial origin (Ibrahim et al., 2006; Campos et al., 2009). Physical aggression resulting in embryonic induction could be one probable cause. This phenomenon was described by Spemann (1938 as cited in Wammes et al., 2013), who discovered that a malfunction in cell division is responsible for the quantitative increase in the production of cells, as occurs in polydactyly and supernumerary organs. Incomplete separation of primitive cell lines results in incompletely separated (Siamese) twins or polymelia (Wammes et al., 2013).

Acquired congenital malformations are those caused by external factors that do not change the genetic code. However, due to a lack of knowledge regarding their specific causes, such changes are usually treated as genetic and used as a reason to exclude animals from breeding lines due to the fear that malformations may be repeated in the offspring (Werner, 2011).

Scientific knowledge regarding the cause of polymelia is still limited, and a proper diagnosis should be made to establish whether the defect is due to genetic, environmental, or multifactorial causes. It is recommended that the veterinarian surgically extirpate the accessory limb so that its weight does not harm the gait of the animal in its adult life (Montes et al., 2012).

The objective of this study is to report a case of polymelia in a sheep, with a likely environmental cause, which resulted in a satisfactory postoperative outcome and reproductive life.

\section{History}

A female sheep of one year and three months of age and no defined breed was sent to the Veterinary Hospital of the Integrated Faculties of the Educational Union of Planalto Central (Centro Universitário do Planalto Central Apparecido dos Santos; UNICEPLAC), Brasília, Distrito Federal, Brazil. The animal received a diagnosis of thoracomelia, a congenital malformation characterized by the presence of a fifth limb attached to the thorax, in this case on the right side (Figure 1).

The accessory limb had a caudal origin to the root of the normal right thoracic limb and was shorter than the functional ones. It had no scapula, and from the distal end of the metacarpal, it had duplicate structures that gave rise to two feet, each with two toes. Because they did not 


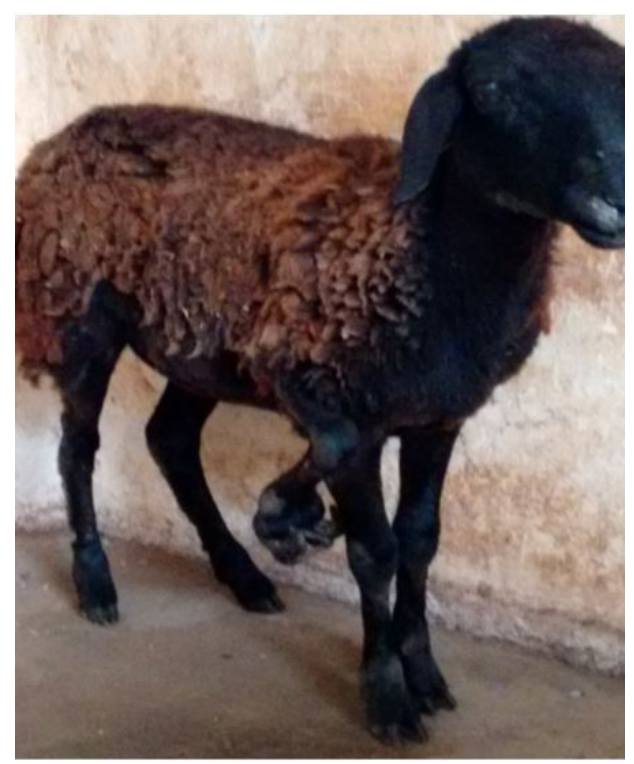

Figure 1. A female sheep with thoracomelia, in this case the extra limb is located in the right thoracic region.

suffer the normal attrition caused by locomotion, as observed in functional limbs, the nails of the accessory limb grew and bent towards the head (Figures 2 and 3).

Despite the congenital defect, the sheep had standard patterns of development and locomotor capacity, and no claudication was observed. However, there was a developing impairment of the functional right front foot, characterized by increased spacing of the toes, possibly due to overweight caused by the accessory limb. Thus, surgical removal of the supernumerary limb was recommended.

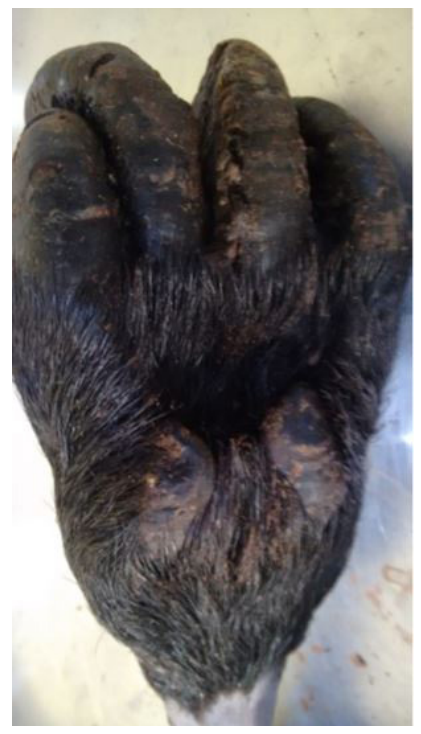

Figure 2. Palmar view of the accessory limb.

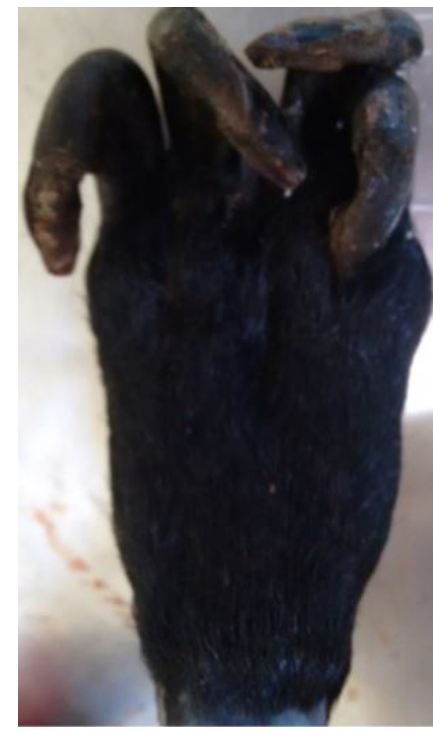

Figure 3. Dorsal view of the accessory limb.

No changes in vital or hematological parameters were identified in the preoperative examinations. A radiographic examination was performed to determine the location of the accessory limb attachment site in the thorax (Figure 4).

After fasting (water and food), the animal was submitted to a wide trichotomy of the accessory limb and the region of its attachment (Figure 5), and positioned in the left lateral decubitus position. The anesthetic protocol adopted was the intravenous application of a pre-anesthetic drug: $0.05 \mathrm{mg} / \mathrm{kg}$ of $2 \%$ xylazine $\left(\right.$ Anasedan ${ }^{\circledast}$ ). Local anesthesia was then performed with lidocaine 


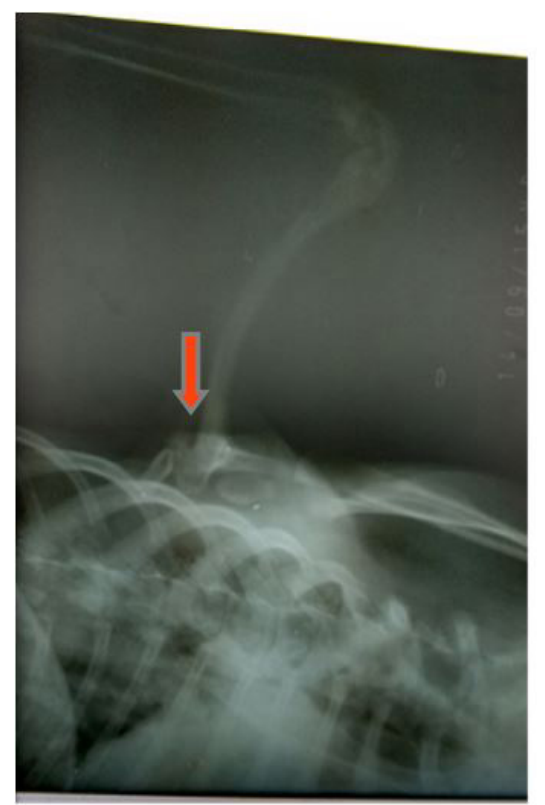

Figure 4. Radiographic image of the accessory limb attachment site (arrow).

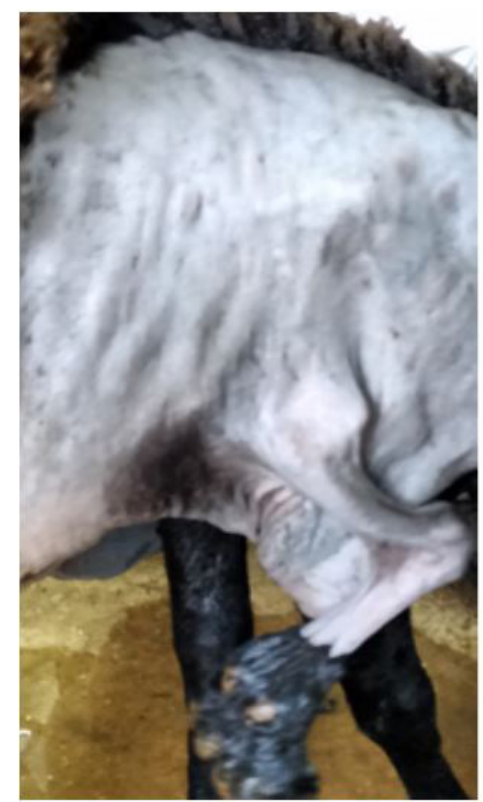

Figure 5. Preoperative trichotomy of the thorax and accessory limb.

hydrochloride without vasoconstrictor (Xylestesin 2\%) through a subcutaneous infiltration anesthesia block (10 mL) with an 18G catheter, and a deep and circular infiltration block with a $22 \mathrm{G}(25 \times 7)$ needle $(5 \mathrm{~mL})$. After one hour of surgery, $1.5 \mathrm{mg} / \mathrm{kg}$ of $10 \%$ ketamine was administered intravenously due to the movements of the animal.

Antisepsis was performed with povidone and iodized ethanol. The hoof was wrapped with a sterile surgical glove. The distal end of the supernumerary limb and the region around the surgical incision site were covered with sterile cloth.

An elliptical incision of approximately $20 \mathrm{~cm}$ was made in the skin around the attachment site of the supernumerary limb, in the caudal direction to the scapula. The subcutaneous tissue was cut, and exposed blood vessels were isolated and ligated with 2-0 polyglactin 910 suture. As there was no bone structure connecting the supernumerary limb to the animal's body, only a structure of approximately $3 \mathrm{~cm}$ in width, similar to the cartilaginous tissue, was sectioned. The subcutaneous layer was sutured to bring the tissues closer together, reducing the dead space with continuous single stitches using 2-0 polyglactin 910 suture. The skin was then sutured with No. O nylon suture in the Wolff pattern. Plasty was performed to remove the excess skin at the edges of the elliptical wound (Figure 6).

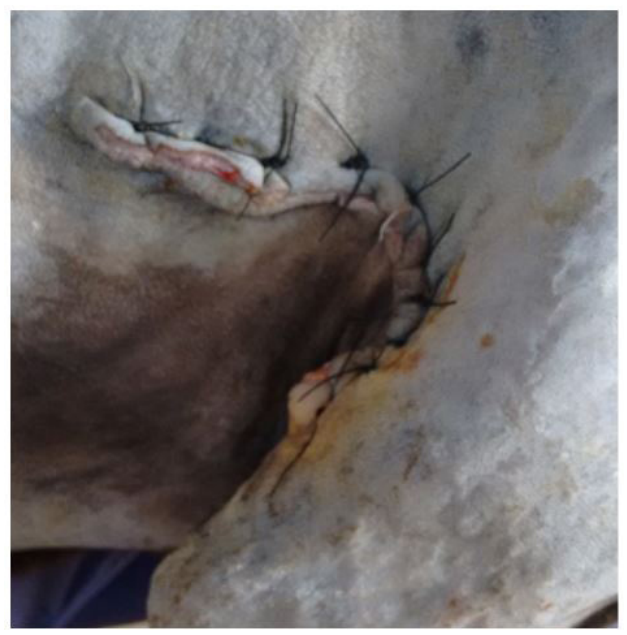

Figure 6. Accessory limb attachment site after surgery. 
In the postoperative period, the animal was medicated with a combination of penicillin antibiotics at a dose of 30,000 IU/kg based on the concentration of benzathine penicillin diluted with distilled water. This was administered intramuscularly every 48 hours for ten days. Flunixin meglumine was injected intramuscularly at a dose of $1.1 \mathrm{mg} / \mathrm{kg}$ every 24 hours for three days. Daily dressing was performed with cleaning of the wound using povidone-iodine diluted in $1 \%$ saline solution and rifampicin spray. This was followed by bandaging for twelve days until the removal of the suture. No postoperative complications were observed, and the surgical method used was functionally and aesthetically efficient in terms of treatment.

After the surgical procedure, the extirpated limb was dissected. After the skin was removed, the accessory limb was found to be wrapped in fibrous connective tissue with a root consisting of the head of the radius, humerus, and olecranon (Figure 7). The humerus consisted only of the condyle (distal portion) and part of the body, so that its entire length was approximately the same as that of the olecranon and head of the radius (Figure 8), the latter having a conformation similar to that of the olecranon. The presence of atrophied musculature was observed deep into the fibrous connective tissue, and in the palmar direction to the ulna (Figure 9).

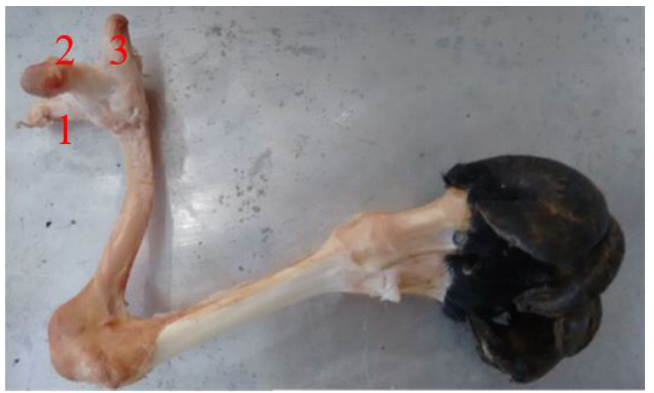

Figure 7. Limb after skin removal, covered with fibrous connective tissue. The root is formed by (1) head of the radius; (2) humerus; and (3) olecranon.

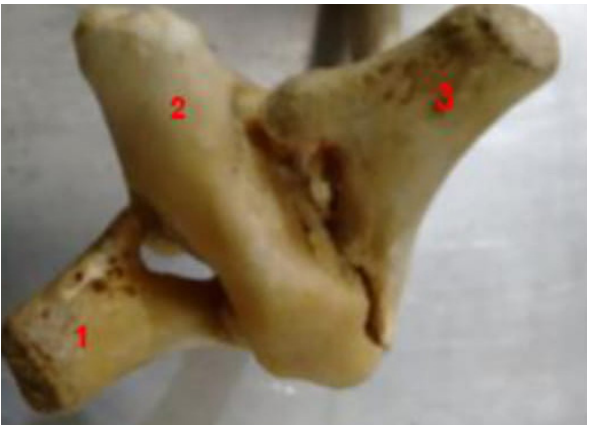

Figure 8. Bones of the accessory limb: (1) olecranon; (2) humerus; and (3) head of the radius.

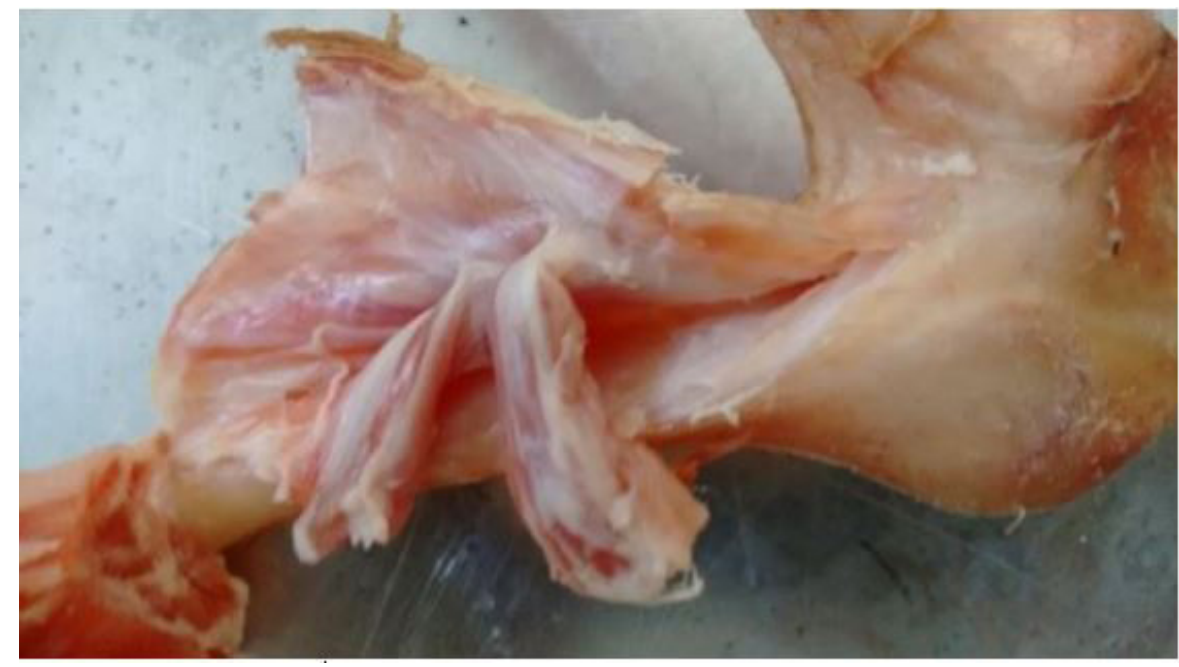

Figure 9. Atrophied musculature.

The proximal end of the humerus was surrounded by a fibrocartilaginous structure. The bone formation of the limb presented a duplication of the structures from the metacarpal head, observing four trochleae for articulation with the respective phalanges (Figure 10). The distal phalanges fragmented during the dissection process due to intense bone demineralization, which was present in all structures and evident in the proximal phalanges (Figure 11).

After the surgical procedure, the sheep was kept in the breeding line and had two pregnancies, which resulted in two descendants without congenital malformations (Figure 12). 


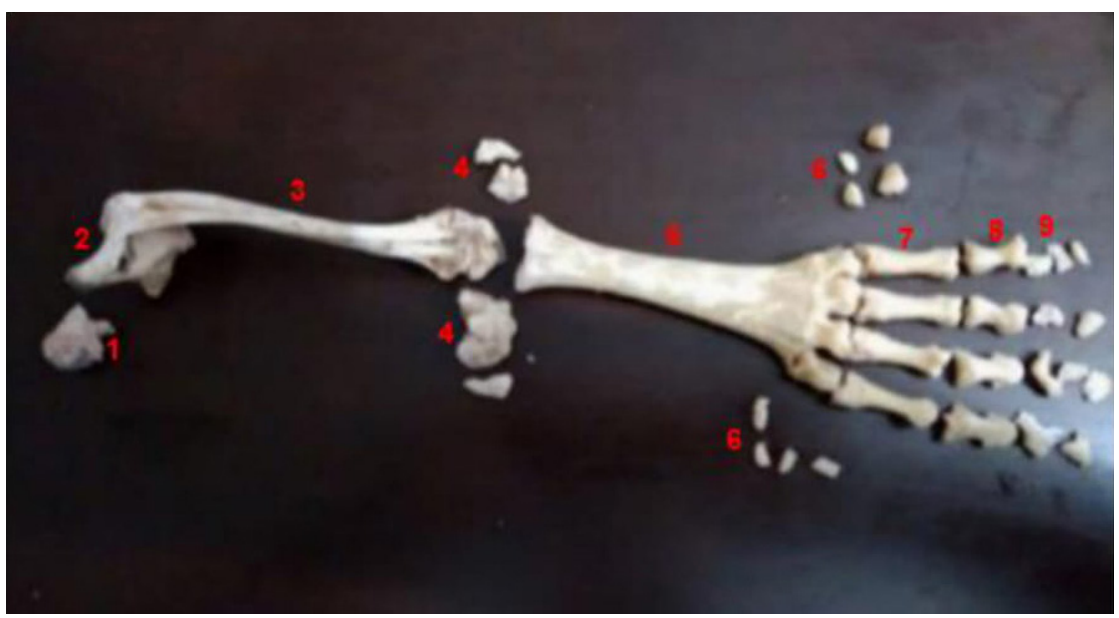

Figure 10. Bone structure of the accessory limb: (1) fibrocartilaginous structure involving the proximal region of the humerus; (2) olecranon, humerus, and head of the radius; (3) radius; (4) carpal bones; (5) metacarpal; (6) sesamoid bones; (7) proximal phalanges; (8) medium phalanges; and (9) fragmented distal phalanges.

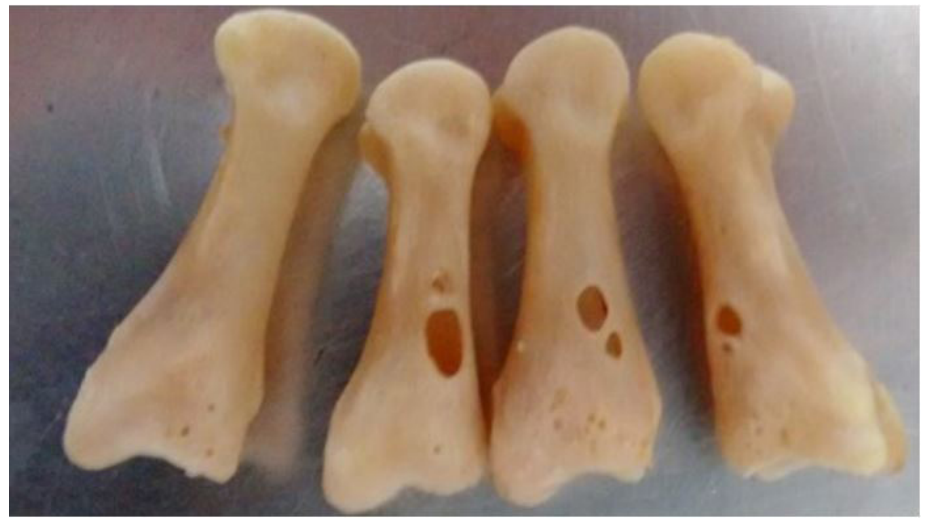

Figure 11. Proximal phalanges with evidence of demineralization.

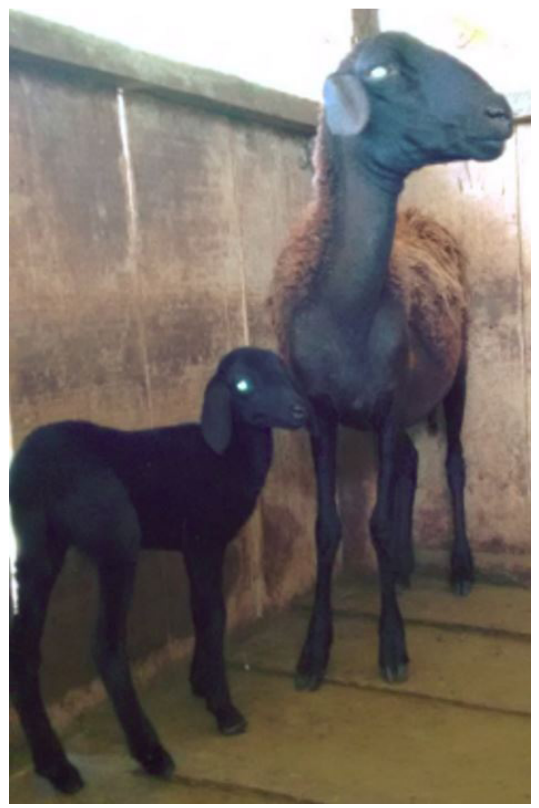

Figure 12. Sheep subject to accessory limb removal and her descendant with no congenital malformations. 


\section{Discussion and conclusion}

Based on the criteria presented by Werner (2011), the malformation observed in this study was an instance of thoracomelia. In this case, it was characterized by the presence of a supernumerary limb in the right thoracic region, probably caused by death or injury of embryonic cells.

Despite the congenital defect, the sheep showed similar development and locomotion capacity to other sheep without this malformation. However, a developing impairment of the functional right front foot was observed, characterized by increased spacing of the toes (Figure 13), possibly due to overweight caused by the accessory limb. This change highlights the importance of surgical removal of the accessory limb: so that its weight does not impair the gait of the animal in its adult life, as suggested by Montes et al. (2012).

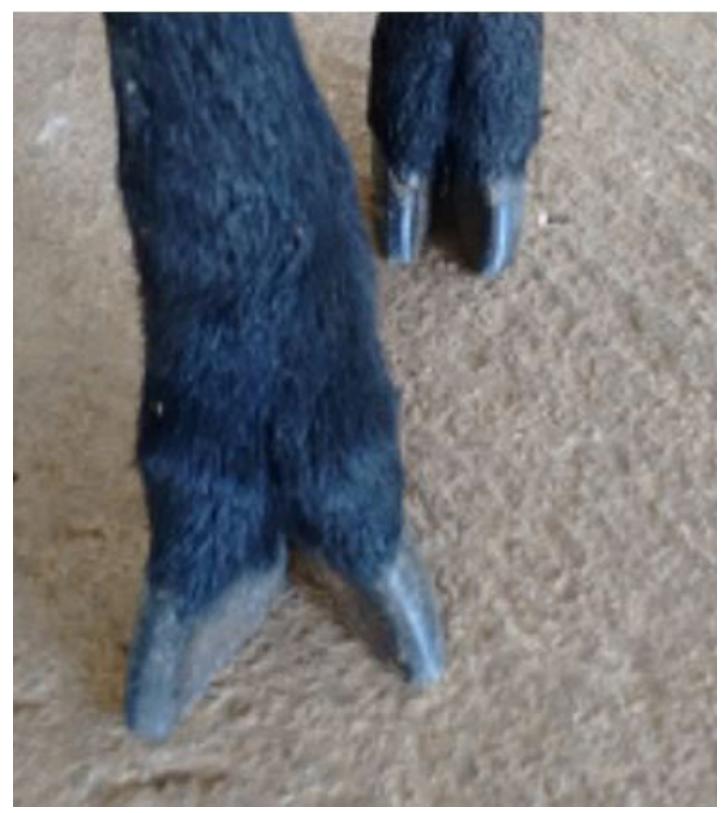

Figure 13. Functional right thoracic limb showing spacing between digits, probably due to the additional weight of the accessory limb.

Regarding the cause of the congenital change, in the rural property of the sheep's origin, sheep have been raised for more than three decades. The owner does not know the precise year in which sheep farming started and has had no previous cases of malformation. Thus, toxic plants should not be considered the cause of this malformation because, as noted by Nóbrega Junior et al. (2005), this etiology would be associated with high incidence rates of the malformation.

We were informed that there was no inbreeding between the progenitors of the studied animal. However, due to the fear that the malformation had been caused by genetic factors, the reproducing ram was removed from the herd, although it was evaluated by the owner as being morphologically healthy and none of its other offspring had presented with congenital abnormalities. This preventive procedure corroborates Werner's (2011) assessment that a lack of knowledge regarding the causes of malformation, along with a fear of transmitting deleterious characteristics to offspring, leads owners to assume that such anomalies always have a genetic cause. Thus, they choose to remove malformed progenitors from the breeding line.

However, the mother of the malformed sheep remained in the herd and generated two healthy lambs with no thoracomelia. After the removal of the accessory limb, the sheep with thoracomelia also remained in the breeding line and, in two pregnancies, gave birth to two descendants without congenital defects.

The lack of other records of similar occurrences on the property indicates that there is likely no inbreeding between the progenitors of the sheep with thoracomelia, especially as this sheep generated healthy offspring. The hypothesis that this malformation could have a genetic origin, 
as presented by Canola et al. (1993), Werner (2011), and Anjos et al. (2015), was not confirmed in this case report.

However, the owner reported that during the period of embryonic development of the malformed sheep, a dog attacked the herd, leaving some animals dead and many injured. Such an extreme situation of physical aggression supports the hypothesis that the polymelia in this case was caused by environmental factors and could be related to the attack suffered during embryonic development, as suggested by Selye (1976), Acco et al. (1999), and Wammes et al. (2013).

Considering that thoracomelia is due to environmental factors, the risk of its occurrence among sheep would not be altered by genetic management strategies. Thus, to avoid new occurrences, we recommended care strategies to the owner that would reduce the possibility of further dog attacks or other physical aggressions to sheep during the period of embryonic development.

Congenital defects like thoracomelia are observed rarely in sheep, and an understanding of their causes is limited due to the non-referral of animals with congenital abnormalities for laboratory analysis (Pereira et al., 2010; Wammes et al., 2013; Paukovics, 2013). Thus, this case report can contribute to the advancement of scientific knowledge on the subject, in the context of veterinary medicine.

\section{References}

Acco, A., Pachaly, J. R., \& Bacila, M. (1999). Síndrome do estresse em animais: revisão. Arquivos de Ciências Veterinárias e Zoologia da Universidade Paranaense, 2(1), 71-76.

Anjos, C., Garcia, F. G., Magalhães, L. Q., Teixeira, B. S., Saut, J. P. E., \& Nogueira, G. M. (2015). Correção cirúrgica de polidactilia unilateral em potro: relato de caso. Revista Brasileira de Medicina Equina, 62, 10-14.

Campos, K. F., Sousa, M. G. S., Silva, N. S., Oliveira, C. H. S., Duarte, M. D., Barbosa, J. D., \& Oliveira, C. M. C. (2009), Doenças congênitas em bovinos diagnosticadas pela Central de Diagnóstico Veterinário (CEDIVET) da Universidade Federal do Pará, no período de 1999 a 2009. Ciência Animal Brasileira , (Suppl. 1), 13-19.

Canola, J. C., Marques, J. A., \& Campebell, R. C. (1993). Polidactilia em potros: relato de cinco casos. Ars Veterinária, 9(1), 10-17.

Cebrián, L. M., Varela, E., Ciudad, M. J., \& Ramos, J. J. (2006). Polimelia em uma ternera frisona de ocho dias de edad: tratamiento quirúrgico (2 p.). España: Comunicaciones Libres, Associación de Especialistas em Medicina Bovina de España. Retrieved in 2017, November 18, from http://www.gtvzaragoza.com/publicaciones.php.

Ibrahim, N. D., Adamu, S., Useh, S. M., Salami, S. O., Fatihu, M. Y., Sambo, S. J., Mohammed, B., Ojo, S. A., \& Esievo, K. A. (2006). Multiple congenital defects in a bunaji bull. Nigerian Veterinary Journal, 27(3), 80-86.

Montes, V. D., Espitia, P. A., \& Prieto, M. E. (2012). Descripción de polimelia em un ternero Brahman comercial. Reporte de um caso. Revista Colombiana de Ciência Animal, 4(1), 259-265.

Nóbrega Junior, J. E., Riet-Correa, F., Nóbrega, R. S., Medeiros, J. M., Vasconcelos, J. S., Simões, S. V. D., \& Tabosa, I. M. (2005). Mortalidade perinatal de cordeiros no semi-árido da Paraíba. Pesquisa Veterinária Brasileira, 25(3), 171-178. http://dx.doi.org/10.1590/S0100-736X2005000300008.

Paukovics, G. (2013). Congenital anomalies of animals in written and pictorial sources. Archeometriai Mühely, $X(4), 243-248$.

Pereira, C. M., Schild, A. L., Soares, M. P., Vargas Junior, S. F., \& Riet-Correa, F. (2010). Defeitos congênitos diagnosticados em ruminantes na região sul do Rio Grande do Sul. Pesquisa Veterinária Brasileira, 30(10), 816-826. http://dx.doi.org/10.1590/S0100-736×2010001000003.

Selye, H. (1976). Stress in health and disease (pp. 246-391). United States of America: Library of Congress.

Wammes, J. C. S., Domingos, R. F., Prestes, F. O., Philadelpho, A. L., Birck, A. J., \& Barcelos, R. P. (2013). Polimelia em ave: relato de caso. Revista Científica Eletrônica de Medicina Veterinária, 11(20), 1-8.

Werner, P. R. (2011). Anomalias no desenvolvimento. In P. R. Werner (Ed.), Patologia geral veterinária aplicada (pp. 81-102). São Paulo: Roca. 